\title{
The Assessment of Changes in Cognitive Functioning: Reliable Change Indices for Neuropsychological Instruments in the Elderly - A Systematic Review
}

\author{
Janine Stein ${ }^{a} \quad$ Melanie Luppa $^{a} \quad$ Elmar Brähler $^{b}$ Hans-Helmut König ${ }^{c}$ \\ Steffi G. Riedel-Heller ${ }^{\text {a, }} \mathrm{d}$ \\ a Department of Mental Health, Clinic of Psychiatry and Psychotherapy, Public Mental Health Research Unit, \\ ${ }^{b}$ Department of Medical Psychology and Medical Sociology, ' Department of Psychiatry, Health Economics \\ Research Unit, and ${ }^{\mathrm{d}}$ Department of Social Medicine, University of Leipzig, Leipzig, Germany
}

\section{Key Words}

Reliable change indices - Neuropsychological test •

Cognitive change $\cdot$ Change norms $\cdot$ Dementia

\begin{abstract}
Background/Aims: The determination of meaningful cognitive change over time is essential for the diagnosis of dementia in the elderly. Reliable change indices ( $\mathrm{RCls}$ ) represent a suitable methodology to assess clinically significant cognitive change. The purpose of this paper is to provide a systematic review of $\mathrm{RCl}$ scores in elderly persons for neuropsychological tests currently available. Methods: A comprehensive literature search was conducted. Longitudinal studies dealing with the assessment of RCls for cognitive instruments and cognitively healthy older participants were reviewed. Quality of studies was determined using a standardized system of evaluating methodical quality. $\boldsymbol{R e}$ sults: A total of 11 studies met the inclusion criteria; half of the studies rated highly for methodical quality. $\mathrm{RCl}$ scores were summarized for a number of neuropsychological instruments. Conclusion: $\mathrm{RCls}$ have important implications regarding the interpretation of change in test scores in older adults. Further assessment and standardization is needed for many neuropsychological instruments.
\end{abstract}

Copyright $\odot 2010$ S. Karger AG, Basel

\section{Introduction}

Consistent with the worldwide demographic trend of population aging, dementia and associated disorders in the elderly are expected to become one of the most burgeoning public health problems [1]. Due to these developments, there is a rising need for reliable and valid neuropsychological instruments to track cognitive functioning over time and for the diagnosis of dementia. A central issue in clinical and research settings is the distinction between normal age-associated cognitive decline and subclinical cognitive deficits, which may characterize an intermediary stage between the normal variation of scores and dementia [2]. The diagnosis of dementia as well as the diagnosis of mild cognitive impairment requires evidence of cognitive decline over time [3,4]. Furthermore, reliable information on the rate of progression of cognitive impairment in dementia is important for planning therapeutic provisions and long-term care for patients and caregivers.

If psychometric instruments are used to measure cognitive functioning over time, they have to be sensitive or responsive to change. Detecting cognitive change is an important task for clinicians, especially for those working in geriatric settings. Observed cognitive decline in elderly patients' cognitive status may be caused by a variety of processes, including practice effects, normal aging pro-

\section{KARGER}

Fax +41613061234 E-Mail karger@karger.ch www.karger.com
Janine Stein, Department of Mental Health, Clinic of Psychiatry and Psychotherapy Public Mental Health Research Unit, University of Leipzig

Semmelweisstrasse 10, DE-04103 Leipzig (Germany)

Tel. +49341972 4494, Fax +493419724539

E-Mail Janine.Stein@medizin.uni-leipzig.de 
Table 1. Criteria for evaluating methodical quality of studies assessing RCIs

A positive score of 2 applied if ${ }^{\mathrm{a}}$

1 Study sample is nationally or regionally representative of the elderly population of the country

2 Sample inclusion and/or exclusion criteria are formulated

3 Information on participant lost-to-follow-up is reported

4 The process of data collection is described (e.g. interview or self-report)

5 Training and quality control methods for interviewers' technique/data collection are applied

6 Definition of the outcome criteria RCI: established concepts/methods are applied and described

7 Detailed information about study design (baseline, follow-up, test-retest-intervals) is reported

8 Descriptive data (mean or median and range or standard deviation) are provided for outcome measures

9 Characteristics of study participants (sociodemographic, clinical) are given

10 Data about assessment/diagnosis of cognitive status of study participants are reported

11 Reliability and/or validity of study instruments is reported

12 Detailed description of statistical analyses is given

13 Participants signed an informed consent form before study entry

14 Potential influences of several variables (e.g. age, gender, education) on the outcome measure are considered

15 Precision of estimates is given (e.g. 95\% confidence interval)

Adapted from Gaugler et al. [13], Mols et al. [14] and Luppa et al. [15].

a A score of 2 = fully met the quality criterion; 1 = partially met the quality criterion; $0=$ did not meet the quality criterion.

cesses or therapeutic and medical conditions [5]. Methods for measuring change over time [for an overview, see e.g. $6,7]$ include the standard deviation (SD) method, standardized regression-based (SRB) methods and reliable change indices (RCIs). Jacobson and Truax [8] introduced one of several statistical methods of identifying clinically meaningful (or significant) changes in individual test scores. To determine whether or not the extent of change was statistically reliable, they proposed a RCI. The essential elements of the RCI formula are the observed change score of a person (post-test score minus pre-test score) in the numerator and the standard error of difference between the 2 scores in the denominator. Expressed as an effect size and based on the standard error of measurement, the RCI measure ensures that the degree of change was of sufficient magnitude and not due to chance or measurement error. In recent years, more refined and modified methods to compute RCIs than those suggested by Jacobson and colleagues have evolved. The RCI method as suggested by Chelune et al. [9] accounts for measurement error and practice effects by subtracting the practice score for the normative group (group mean post-test score minus group mean pre-test score) from a person's change score. The RCI as suggested by Hsu [10] adjusts for the effects of regression to the mean by taking the test-retest reliability into account. In general, RCI values exceeding +1.645 and falling below -1.645 ( $\alpha=0.10$ for two-tailed prediction) are usually defined as reliable change in test scores (i.e. reliable improvement or reliable deterioration). All formulas for calculating RCIs are available in Appendix 1 . In comparison with other change score methods (e.g. regression-based methods), these 2 RCI methods show some advantages. In detail, they were found to be especially appropriate for the accurate classification of normal cognitive change in the elderly [7]. Furthermore, they might be easier to compute for clinical practitioners than more complex multiple regression methods.

In recent years a variety of studies have been published evaluating RCIs for different psychometric instruments. The objectives of this review were: (1) to systematically obtain and evaluate the relevant literature on the assessment of RCIs for neuropsychological instruments in the elderly population, and (2) to provide an overview and information source about available RCI scores for neuropsychological tests for clinical and research settings.

\section{Methods}

Search of the Literature

A systematic literature search of relevant publications in the electronic databases MEDLINE, Web of Science, Cochrane Library, PSYNDEXplus and in the bibliographies of identified articles was conducted. Search key words were 'reliable change index/indices', 'change norms', 'cognitive change' and 'test*' or 'instrument*'. Criteria for inclusion were as follows:

(1) Published studies with the objective to compute RCIs.

(2) The study assesses RCI values for neuropsychological instruments and cognitive abilities.

(3) Samples of included studies should be representative for the general population. For example, studies with highly selected samples (e.g. only men or HIV patients) were excluded.

(4) Consisting of cognitively healthy older individuals with a mean age of 45 years and older to provide a reliable discrimination between normal and pathological cognitive aging processes. We decided to set the study participant's mean age threshold at 45 years in order to cover a broad age and dementia onset range. As several clinical studies [11, 12] showed, dementia can manifest itself as a clinically heterogeneous disorder depending on the age of onset. One can differentiate between earlyonset Alzheimer's disease (onset before 65 years of age), lateonset Alzheimer's disease (onset after 65 years of age) or youngonset dementia (onset before the age of 45 years). 


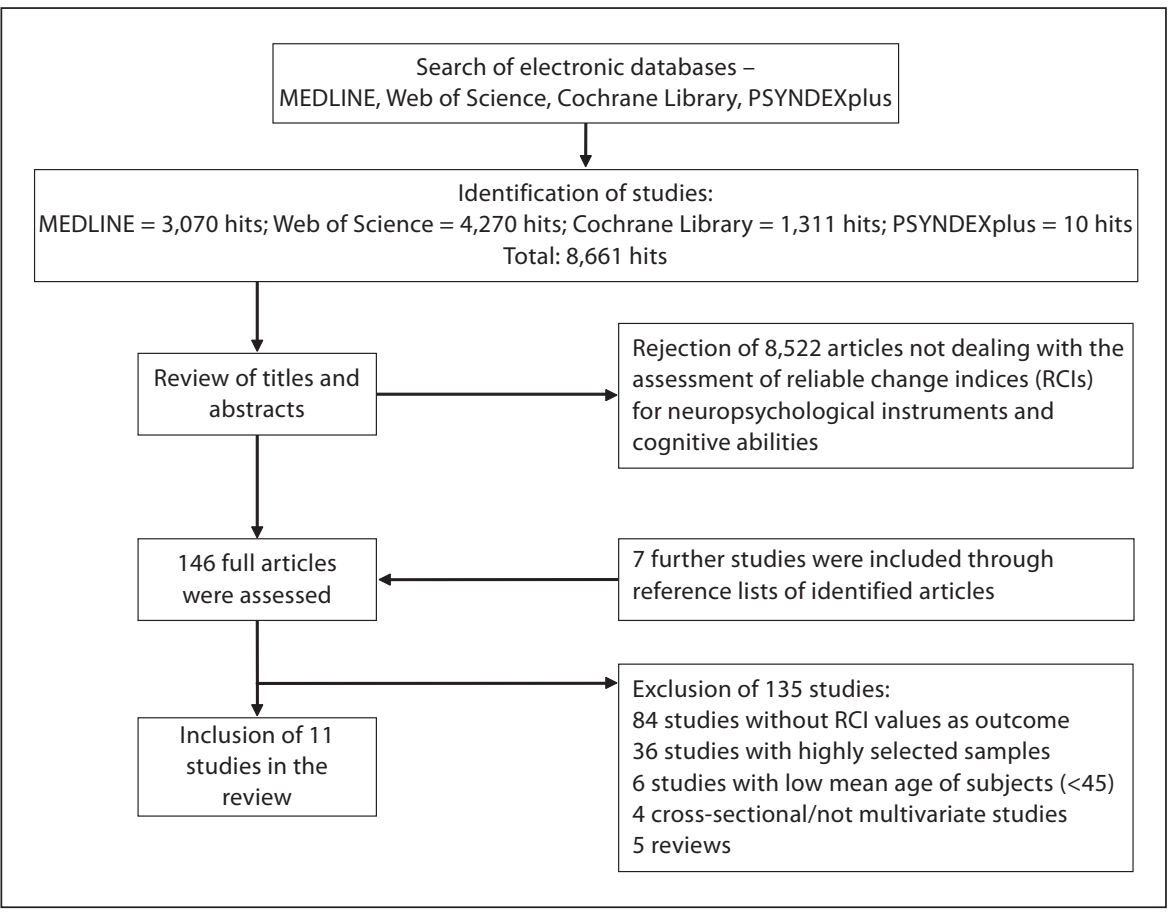

Fig. 1. Flowchart showing the process of the systematic literature search.

(5) The study presents detailed methodical characteristics to facilitate application and evaluation of change norms.

(6) A longitudinal (prospective) study design to assess and appraise cognitive changes.

\section{Quality Assessment}

The methodical quality of the studies was independently evaluated by the principal author (J.S.) and co-author (M.L.) using an adapted version of standardized criteria and a modified scoring system applied in other systematic reviews (table 1) [13-15]. Each item was scored as 2 (fully met the quality criterion), 1 (partially met the quality criterion) or as 0 (did not meet the quality criterion). The maximum quality score was 30 . Studies scoring in the 75 th percentile or higher on quality (quality score of 23 or above) were categorized as 'high quality' studies. Studies scoring between 50 and 75\% (quality score between 15 and 22) were rated as 'moderate quality', and studies scoring lower than 50\% (quality score $<15$ ) were considered 'low quality'.

\section{Results}

\section{Literature Search Results}

The initial search strategy conducted in March 2009 identified 8,661 potentially relevant papers, of which 8,522 were excluded based on the initial review of their titles and abstracts. Seven further studies were found in reference lists of identified articles and added to the remaining 139 articles. A total of 146 full articles were retrieved and reviewed for final inclusion; however, 135 more studies had to be rejected because they did not meet the selection criteria. Finally, the literature search (fig. 1) identified 11 studies which were assessed and subjected to the detailed analysis.

\section{General Characteristics}

With regard to the development of RCI concepts, studies were published between 1999 and 2007. The studies were mainly conducted in the USA and Canada; most others were in Europe, one in Australia and one in New Zealand.

\section{Methodical Quality}

The assessment of the methodical quality of the 11 studies by the 2 reviewers (J.S. and M.L.) yielded the following results. The mean quality score was $20(\mathrm{SD}=4.77)$ and ranged from 13 to 25 points. Five studies (45.4\%) were of high quality, 4 studies (36.4\%) of moderate quality, and 2 studies (18.2\%) of low quality. Methodical shortcomings relating to the quality of the studies were mainly the small samples sizes and wide age ranges of study samples, a lack of training and quality methods for interviewers' technique, a deficient assessment/diagnosis of participants' cognitive status at baseline and during the course of the study, and missing reports of psychometric characteristics of used instruments. The quality scores are displayed in table 2 . 
Table 2. Methodical characteristics and RCIs for the studies reviewed

\begin{tabular}{|c|c|c|c|c|c|c|c|}
\hline \multirow{2}{*}{$\begin{array}{l}\text { Neuropsychological } \\
\text { tests/subtests }\end{array}$} & \multirow{2}{*}{$\begin{array}{l}\text { Study/ } \\
\text { year/ } \\
\text { country }\end{array}$} & \multirow{2}{*}{$\begin{array}{l}\text { Study } \\
\text { quality } \\
\text { (score) }\end{array}$} & \multicolumn{3}{|l|}{ Sample } & \multirow{2}{*}{$\begin{array}{l}\text { Study period/ } \\
\text { test-retest } \\
\text { intervals }\end{array}$} & \multirow[t]{2}{*}{ Change scores/RCIs } \\
\hline & & & setting & $\mathrm{n}$ & age & & \\
\hline $\begin{array}{l}\text { Boston Naming Test } \\
\text { (BNT; 60-item version } \\
\text { without cueing) }\end{array}$ & $\begin{array}{l}\text { Zec et al. [19]; } \\
\text { 2005; USA }\end{array}$ & $\begin{array}{l}\text { Moderate } \\
(21)\end{array}$ & $\begin{array}{l}\text { Community- } \\
\text { dwelling }\end{array}$ & 353 & $\begin{array}{l}M=67.25 \\
(S D=8.27) \\
\text { range: } 50-99\end{array}$ & $\begin{array}{l}2 \text { assessments/ } \\
9 \text { - to } 15 \text {-month } \\
\text { interval }\end{array}$ & $\begin{array}{l}\text { RCI }(95 \% \text { CI })^{\mathrm{a}} \text { : } \\
\text { RCI/age group (years): } \\
2.80 / 50-59 \\
3.31 / 60-69 \\
3.52 / 70-79 \\
4.59 / 80-89 \\
\text { RCI/education (years): } \\
3.04 /<12 \\
3.76 /=12 \\
3.36 />12 \\
\text { RCI/gender: } \\
3.66 / \text { females } \\
3.14 / \text { males } \\
\text { RCI (overall): } 3.48\end{array}$ \\
\hline $\begin{array}{l}\text { California Verbal Learning } \\
\text { Test - second edition } \\
\text { (CVLT-II) } \\
\text { Primary measures: }\end{array}$ & $\begin{array}{l}\text { Woods et al. [26]; } \\
\text { 2006; USA }\end{array}$ & $\begin{array}{l}\text { Moderate } \\
(15)\end{array}$ & $\begin{array}{l}\text { No information } \\
\text { provided }\end{array}$ & $\begin{array}{r}80 \\
115\end{array}$ & $\begin{array}{l}M=49.5 \\
(S D=22.7) \\
\text { range: } 16-88 \\
M=47.7 \\
(S D=22.0) \\
\text { range: } 16-88\end{array}$ & $\begin{array}{l}2 \text { assessments/ } \\
\text { mean interval }= \\
29 \text { days }(\mathrm{SD}=13 ; \\
\text { range }=9-74)\end{array}$ & $\begin{array}{l}\text { RCI }(90 \% / 95 \% \mathrm{CI})^{\mathrm{b}, \mathrm{c}} \text { : } \\
\text { RCI values based on } \\
90 \% / 95 \% \text { CI are also } \\
\text { provided for CVLT-II } \\
\text { process measures }\end{array}$ \\
\hline $\begin{array}{l}\text { Standard/standard forms } \\
\text { (baseline/follow-up, } \mathrm{n}=80 \text { ): } \\
\text { Total trials } 1-5 \\
\text { Short-delay free recall } \\
\text { Short-delay cued recall } \\
\text { Long-delay free recall } \\
\text { Long-delay cued recall } \\
\text { Total recognition } \\
\quad \text { discriminability }\end{array}$ & & & & & & & $\begin{array}{l}-5.38 ; 20.98 /-7.90 ; 23.50 \\
-2.34 ; 5.06 /-3.05 ; 5.77 \\
-1.80 ; 4.52 /-2.40 ; 5.12 \\
-1.82 ; 4.70 /-2.44 ; 5.32 \\
-1.97 ; 4.65 /-2.60 ; 5.28 \\
-0.55 ; 1.03 /-0.70 ; 1.18\end{array}$ \\
\hline
\end{tabular}

Standard/alternate forms

(baseline/follow-up, $\mathrm{n}=115$ ):

Total trials 1-5

Short-delay free recall

Short-delay cued recall

Long-delay free recall

Long-delay cued recall

Total recognition

discriminability

$2.99 ; 15.66 /-15.74 ; 18.40$

$-4.03 ; 5.37 /-4.94 ; 6.28$

$-3.69 ; 4.67 /-4.49 ; 5.47$

$-3.99 ; 4.93 /-4.84 ; 5.78$

$-3.92 ; 4.70 /-4.75 ; 5.53$

Dementia Rating Scale (DRS)

Pedraza et al. [22]

Moderate Community-

dwelling

$-1.15 ; 1.13 /-1.36 ; 1.34$

\begin{tabular}{|c|c|c|c|c|c|c|c|}
\hline 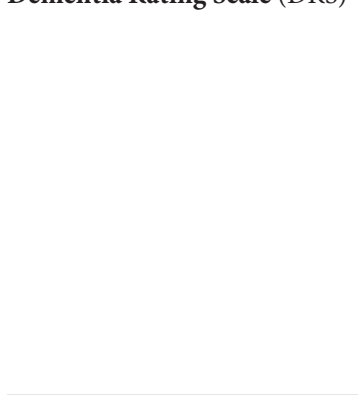 & 2007; USA & (21) & $\begin{array}{l}\text { dwelling } \\
\text { (participants } \\
\text { of MOANS/ } \\
\text { MOAANS } \\
\text { series) }\end{array}$ & & $\begin{array}{l}(\mathrm{SD}=7.3) \\
\text { range: } 65+\end{array}$ & $\begin{array}{l}2 \text { intervals: } \\
9-15 \text { months } \\
\text { and } \\
16-24 \text { months }\end{array}$ & $\begin{array}{l}\text { Time interval } 9-15 \text { months: } \\
-7 \geq \mathrm{RC} \leq+10 \text { (all subjects) } \\
-6 \geq \mathrm{RC} \leq+9 \text { (European } \\
\text { Americans) } \\
-9 \geq \mathrm{RC} \leq+12 \text { (African } \\
\text { Americans) } \\
\text { Time interval 16-24 months: } \\
-7 \geq \mathrm{RC} \leq+10 \text { (all subjects) } \\
-7 \geq \mathrm{RC} \leq+10 \text { (European } \\
\text { Americans) } \\
-8 \geq \mathrm{RC} \leq+14 \text { (African } \\
\text { Americans) }\end{array}$ \\
\hline $\begin{array}{l}\text { Graded Naming Test } \\
\text { (GNT) } \\
\text { Silhouettes Test } \\
\text { Verbal fluency: } \\
\text { 'Letter S' (phonological) } \\
\text { 'Animals' (semantic) } \\
\text { Modified Wisconsin Card } \\
\text { Sorting Test (MCST): } \\
\text { Total errors (TE) } \\
\text { New Symbol Digit Test }\end{array}$ & $\begin{array}{l}\text { Bird et al. [17]; } \\
\text { 2004; UK }\end{array}$ & $\begin{array}{l}\text { Moderate } \\
(15)\end{array}$ & $\begin{array}{l}\text { Community- } \\
\text { dwelling }\end{array}$ & 188 & $\begin{array}{l}M=57.0 \\
(S D=8.3) \\
\text { range: } 39-75\end{array}$ & $\begin{array}{l}2 \text { assessments/ } \\
1 \text {-month interval } \\
(\mathrm{M}=30.4 \text { days; } \\
\mathrm{SD}=1.4 \text { days })\end{array}$ & $\begin{array}{l}\text { RCI }(90 \% \text { CI })^{\mathrm{b}} \text { : } \\
-1.6 ;+3.5 \\
-2.3 ;+4.5 \\
-5.5 ;+9.8 \\
-7.6 ;+10.5\end{array}$ \\
\hline
\end{tabular}


Table 2 (continued)

\begin{tabular}{|c|c|c|c|c|c|c|c|}
\hline \multirow{2}{*}{$\begin{array}{l}\text { Neuropsychological } \\
\text { tests/subtests }\end{array}$} & \multirow{2}{*}{$\begin{array}{l}\text { Study/ } \\
\text { year/ } \\
\text { country }\end{array}$} & \multirow{2}{*}{$\begin{array}{l}\text { Study } \\
\text { quality } \\
\text { (score) }\end{array}$} & \multicolumn{3}{|l|}{ Sample } & \multirow{2}{*}{$\begin{array}{l}\text { Study period/ } \\
\text { test-retest } \\
\text { intervals }\end{array}$} & \multirow[t]{2}{*}{ Change scores/RCIs } \\
\hline & & & setting & $\mathrm{n}$ & age & & \\
\hline $\begin{array}{l}\text { Mayo Cognitive Factor } \\
\text { Scores (MCFS) } \\
\\
\text { Verbal Comprehension (VC) } \\
\text { Perceptual Organization (PO) } \\
\text { Attention-Concentration (AC) } \\
\text { Learning (LRN) } \\
\text { Retention (RET) }\end{array}$ & $\begin{array}{l}\text { Ivnik et al. [24]; } \\
\text { 1999; USA }\end{array}$ & $\begin{array}{l}\text { High } \\
(23)\end{array}$ & $\begin{array}{l}\text { Clinic-based } \\
\text { (controls for } \\
\text { incident } \\
\text { dementia } \\
\text { patients) }\end{array}$ & 93 & $\begin{array}{l}M=79.1 \\
(\mathrm{SD}=6.4) \\
\text { range: } 54+\end{array}$ & $\begin{array}{l}3 \text { assessments/ } \\
1 \text { - to } 2 \text {-year } \\
\text { interval }\end{array}$ & $\begin{array}{l}\text { Mean change score/RCI } \\
\text { corrected for practice } \\
\text { effects }(90 \% \text { CI): } \\
\pm 10.26 /-8 \leq \mathrm{VC} \leq+12 \\
\pm 13.26 /-8 \leq \mathrm{PO} \leq+19 \\
\pm 13.84 /-12 \leq \mathrm{AC} \leq+16 \\
\pm 17.13 /-11 \leq \mathrm{LRN} \leq+24 \\
\pm 19.72 /-15 \leq \mathrm{RET} \leq+25\end{array}$ \\
\hline $\begin{array}{l}\text { MicroCog } \\
\text { (computerized testing battery): } \\
\text { Attention/Mental Control } \\
\text { Reasoning/Calculation } \\
\text { Memory } \\
\text { Spatial Processing } \\
\text { Reaction Time } \\
\text { Information Processing Speed } \\
\text { Information Processing Accuracy } \\
\text { General Cognitive Functioning } \\
\text { General Cognitive Proficiency }\end{array}$ & $\begin{array}{l}\text { Raymond et al. [18]; } \\
\text { 2006; Australia }\end{array}$ & $\begin{array}{l}\text { Low } \\
(14)\end{array}$ & $\begin{array}{l}\text { Community- } \\
\text { dwelling }\end{array}$ & 40 & $\begin{array}{l}M=64.7 \\
(S D=8.3) \\
\text { range: } 50-83\end{array}$ & $\begin{array}{l}3 \text { assessments/ } \\
2 \text { intervals: } \\
2 \text { weeks and } \\
3 \text { months }\end{array}$ & $\begin{array}{l}\text { RCI + practice }(90 \% \mathrm{CI})^{\mathrm{c}} \\
\pm \mathrm{RCI} \text { after } 2 \text { weeks/ } \\
3 \text { months: } \\
-15.2 ; 29.8 /-17.7 ; 24.5 \\
-13.2 ; 34.2 /-15.6 ; 34.8 \\
-13.9 ; 32.5 /-14.0 ; 33.8 \\
-0.9 ; 49.1 /-12.7 ; 34.7 \\
-17.6 ; 43.6 /-15.1 ; 42.1 \\
-5.2 ; 28.6 /-8.4 ; 28.4 \\
-8.6 ; 30.4 /-11.3 ; 24.3 \\
-4.4 ; 31.8 /-7.8 ; 26.6 \\
-2.5 ; 23.3 /-6.3 ; 19.4\end{array}$ \\
\hline \multirow[t]{2}{*}{ MMSE } & $\begin{array}{l}\text { Hensel et al. [21]; } \\
\text { 2007; Germany }\end{array}$ & $\begin{array}{l}\text { High } \\
(25)\end{array}$ & $\begin{array}{l}\text { Community- } \\
\text { dwelling } \\
\text { (participants } \\
\text { of LEILA } \\
75+\text { ) }\end{array}$ & 119 & $\begin{array}{l}M=79 \\
(S D=3.6) \\
\text { range: } 75-94\end{array}$ & $\begin{array}{l}6 \text { assessments/ } \\
\text { approx. } 1.5 \text {-year } \\
\text { intervals }\end{array}$ & $\begin{array}{l}\text { RCI }(90 \% \mathrm{CI})^{\mathrm{b}, \mathrm{e}} \text { : } \\
\text { Comparison with baseline } \\
\text { (interval in years): } \\
\leq-3 ; \geq+3(1.6) \\
\leq-2 ; \geq+4(2.9) \\
\leq-3 ; \geq+3(4.5) \\
\leq-3 ; \geq+3(6.1) \\
\leq-3 ; \geq+3(7.1) \\
\text { Adjacent assessments } \\
\text { (interval in years): } \\
\leq-3 ; \geq+3(1.4) \\
\leq-3 ; \geq+3(1.5) \\
\leq-3 ; \geq+3(1.6) \\
\leq-3 ; \geq+3(0.9) \\
\leq-2 ; \geq+4 \text { (overall) }\end{array}$ \\
\hline & $\begin{array}{l}\text { Tombaugh [23]; } \\
\text { 2005; Canada }\end{array}$ & $\begin{array}{l}\text { High } \\
(24)\end{array}$ & $\begin{array}{l}\text { Community- } \\
\text { dwelling } \\
\text { (participants } \\
\text { of the CSHA) }\end{array}$ & 160 & $\begin{array}{l}M=76.32 \\
(S D=5.42) \\
\text { range: } 65-89\end{array}$ & $\begin{array}{l}4 \text { assessments/ } \\
2 \text { short intervals } \\
\text { (approx. } 3 \\
\text { months); } \\
2 \text { long intervals } \\
\text { (approx. } 5 \text { years) }\end{array}$ & $\begin{array}{l}\text { RCI-Diff }(90 \% \text { CI, } \\
\text { corrected for practice })^{\mathrm{f}}: \\
\text { Short intervals (mean days): } \\
\pm 4.16(87.3) \\
\pm 4.01(65.1) \\
\text { Long intervals (mean days): } \\
\pm 4.42(1,758.1) \\
\pm 4.10(1,823.2) \\
\pm 3.59(1,670.8) \\
\pm 2.94(1,735.9)\end{array}$ \\
\hline Modified MMSE (3MS) & & & & & & & $\begin{array}{l}\text { Short intervals (mean days): } \\
\pm 11.13(87.3) \\
\pm 10.19(65.1) \\
\text { Long intervals (mean days): } \\
\pm 13.22(1,758.1) \\
\pm 11.82(1,823.2) \\
\pm 9.81(1,670.8) \\
\pm 8.76(1,735.9)\end{array}$ \\
\hline
\end{tabular}


Table 2 (continued)

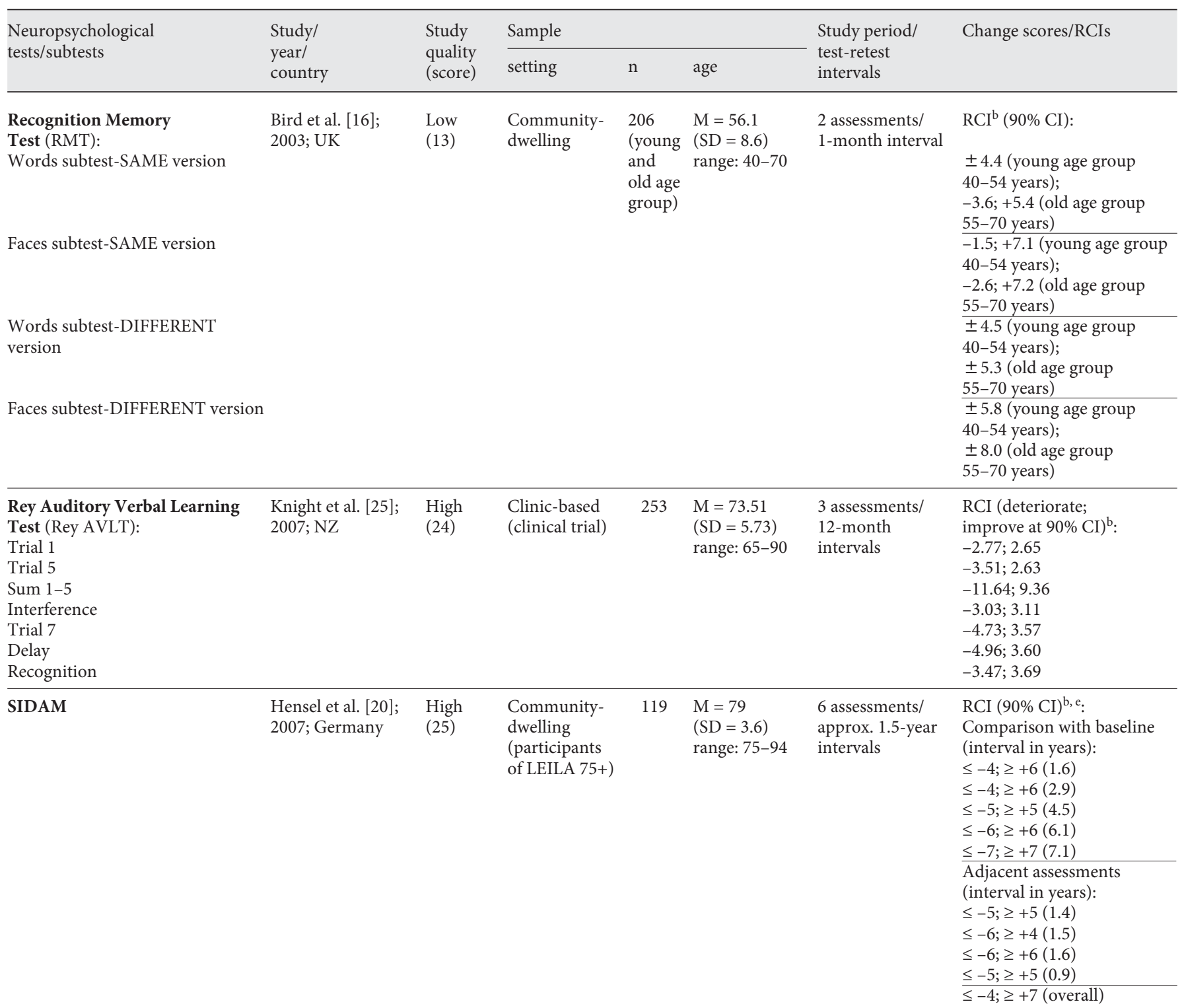

$\mathrm{CI}=$ Confidence interval; $\mathrm{M}=$ mean; MOANS = Mayo's Older Americans Normative Studies; MOAANS = Mayo's Older African American Normative Studies; LEILA 75+ = Leipzig Longitudinal Study of the Aged; CSHA = Canadian Study of Health and Aging. ${ }^{a}$ RCIs based on the standard error of measurement of the difference between the first two assessments. ${ }^{b}$ RCIs, as suggested by Chelune et al. [9], which account for measurement error and practice effects. ${ }^{c}$ RCIs adjusted for practice according to the approach of Temkin et al. [28], where the difference between the actual $\left(\mathrm{T}_{2}\right)$ and the ex- pected retest score is divided by the SD of the difference scores. ${ }^{\mathrm{d}}$ Administration of the Wechsler Adult Intelligence Scale-Revised (WAIS-R), Wechsler Memory Scale-Revised (WMS-R), and the Auditory Verbal Learning Test (AVLT); calculation of the Mayo Cognitive Factor Score (MCFS). ${ }^{\mathrm{e}}$ Data provided for the calculation of RCIs according to Hsu [10], which correct for regression to the mean. ${ }^{\mathrm{f}}$ RCIs according to the method of Jacobson and Truax [8], which used the standard error of measurement to correct for possible measurement error. 


\section{Study Characteristics}

Included studies of this review and methodical characteristics are summarized in table 2. A comparison of studies assessing RCIs for neuropsychological instruments and cognitive abilities showed homogeneity of several methodical aspects.

First, there are similarities in the sample characteristics among these studies. All studies are based on samples of cognitively healthy elderly persons. In general, the studies showed heterogeneous age ranges. Sample sizes ranged from 40 to 1,080 subjects. Two-thirds of the studies consisted of community-dwelling participants [16-19] or individuals who were recruited through the local registry office or their primary care physician within representative ongoing population-based studies on the epidemiology of dementia [20-23]. Other studies included controls who had been followed in an Alzheimer's Disease Patient Registry $[19,24]$. One study reported data from a 2-year clinical trial assessing effects on cognitive performance of lowering homocysteine using dietary supplements. These data were appropriate for the calculation of RCIs, because there was no evidence that lowering plasma homocysteine concentration improves cognitive performance in the elderly [25]. Two of the included papers relied on the same study sample tested at 6 points of time $[20,21]$.

Secondly, all studies had a longitudinal design with study periods ranging from 2 to 6 assessments. Retest intervals between assessments varied between 2 weeks and 5 years among the studies.

Thirdly, the studies have several aspects in common relating to the identification of cognitively unimpaired participants. In some studies, operationalization of 'no cognitive impairment' was realized by patient screenings for histories of medical neurological, or psychiatric, conditions known to adversely affect cognitive functioning, e.g. alcoholism, head injury, Parkinson's disease, stroke or other progressive neurological conditions $[17,18,22$, $24,26]$. Other studies used more refined clinical and neurological examination procedures to assess mental status and normal cognition of potential participants at baseline and during the course of the study, e.g. Mini-Mental State Examination (MMSE) score $\geq 24$ [25], a Structured Interview for the Diagnosis of Dementia of the Alzheimer type, Multi-Infarct Dementia and Dementias of other Etiology (SIDAM) score above age and education specific cutoff scores for mild cognitive impairment [20, 21,27 , evaluation of normal cognition based on self, informant and primary care physician reports [22], and diagnosis of dementia based on diagnostic criteria of the
Diagnostic and Statistical Manual of Mental Disorders (DSM-IV) [4] or on the National Institute of Neurological and Communicative Disorders and Stroke and the Alzheimer's Disease and Related Disorders Association (NINCDS-ADRDA) criteria [19-21,23]. Altogether, most of the studies reported no detailed information about diagnostic criteria.

Table 2 also provides an overview of the psychometric instruments used by studies to assess RCIs for cognitive functioning. While 8 studies concentrated on a single specific instrument, the remaining assessed RCIs for multiple tests or composite measures (e.g. Mayo Cognitive Factor Scores). In Appendix 2 we have summarized the measures used in reviewed studies according to neuropsychological dimensions, cognitive abilities/domains assessed, the subject's task/test format and time for administration of tests. All tests allow administration in clinical practice and/or research settings and most of the instruments are available in several languages. Furthermore, some of them are also available in computerized versions (e.g. MicroCog) or a computerized scoring system is available (e.g. California Verbal Learning Test). The selected tests are among the most commonly used screening measures for mild cognitive impairment and dementia [MMSE, the modified MMSE (3MS), verbal fluency, SIDAM]. Most of the tests presented here assess cognition across one specific neuropsychological dimension (e.g. attention and perception, executive functions, language, learning and memory). In comparison, the Dementia Rating Scale, Mayo Cognitive Factor Scores, MicroCog, MMSE, 3MS and SIDAM cover a broader range of cognitive abilities and domains which are typically decreased in mild cognitive impairment and dementia.

\section{Computation of RCIs}

RCIs for various neuropsychological tests are listed in table 2 (right column). For formulas of different RCI methods, see Appendix 1. These RCI scores were mainly calculated for a $90 \%$ confidence interval; 2 studies used a $95 \%$ confidence level $[19,26]$. More than half of the studies applied the RCI concept suggested by Chelune et al. [9], which defines a reliable change as a change that is unlikely to have occurred by measurement error or by practice effects. Additionally, 2 studies [20,21] provided data for the computation of RCIs according to Hsu [10], which corrects for regression to the mean. Two studies $[18,22]$ reported RCI values according to the model of Temkin et al. [28], which includes a correction for practice effects and refers to the basic RCI procedure by Chelune et al. [9]. Tombaugh [23] provided RCI values (ad- 
ditionally corrected for practice) according to the method of Jacobson and Truax [8], which utilizes the standard error of measurement to correct for possible measurement error. One study [19] reported RCI calculations, which were based on the standard error of measurement of the difference between the first 2 assessments and hence referred to the concept of Jacobson and Truax $[8$, 29]. RCIs were assessed either for single/averaged testretest intervals $(n=6)$ or for multiple test-retest intervals $(\mathrm{n}=5)$. Three studies computed RCIs for different age groups. Moreover, Zec et al. [19] published not only agespecific, but also education- and gender-specific RCI values. Pedraza et al. [22] reported RCIs for different ethnic subject groups.

Two studies focused on the calculation of RCIs for the MMSE [30] and for the Modified MMSE (3MS) [31, 32]. RCI scores were calculated for different test-retest intervals and showed ranges from -2 to +4 and -4 to +4 for the MMSE and scores ranging from -9 to +9 and -13 to +13 for the $3 \mathrm{MS}$. In addition, one study [20] calculated RCIs from $\leq-4$ to $\geq+7$ for the SIDAM, which also contains the MMSE.

\section{Discussion}

The aims of this paper were to conduct a comprehensive review of studies assessing RCIs for neuropsychological instruments measuring cognitive abilities in the elderly population. RCI scores for various neuropsychological tests were summarized to provide information and guidance for practitioners and researchers. Therefore, we focused on existing literature by setting specific and explicit inclusion criteria and by evaluating studies based on their methodical quality. Due to strictly defined selection criteria, there were only 11 studies appropriate for inclusion in this review. Furthermore, we chose specific criteria for the assessment of methodical quality of studies, and quality scoring yielded mostly high to moderate results. The adapted criteria for methodical study quality presented here might serve as guidance for future investigations. In general, the use of selection criteria, checklists, protocols and second observers was intended to reduce selection, observer and interpretation biases.

The studies presented provide RCI scores for various time periods and test-retest intervals. Prior research has shown that cognitive and functional decline occur over different time periods within different dementia syndromes. For example, memory and executive functions showed the greatest decline over time in patients who would develop symptomatic Alzheimer's disease 1.5 years later [33]. Moreover, different patterns of cognitive dysfunction can predict short- and long-term onset of dementia at different ages [34]. Hence, it might be useful to provide RCI values for differing time periods to appropriately track cognitive profiles of impairment and predict dementia. Furthermore, dementia diseases seem to have long prodromal periods, and cognitive deficits are detectable many years before the occurrence of dementia [35]. Thus, studies with more than 2 follow-up visits and over longer time intervals (e.g. 1.5 years) are necessary. However, previous study results indicate that the length of the test-retest interval may influence retest performance in cognitive tests and the occurrence of practice effects [23, 36]. Consequently, the computation of RCI values for shorter time intervals ( $\leq 1.5$ years) might have to be additionally corrected for practice effects or should be based on the use of alternate test forms.

Furthermore, published longitudinal studies on RCIs did not always administer a comprehensive cognitive assessment to identify and exclude cognitive impaired and early dementia cases. Just a few studies excluded patients with mild cognitive impairment and dementia at baseline based on operationalization of cognitive health (e.g. DSM-IV diagnostic criteria). Other studies did not employ a comprehensive cognitive evaluation. For the reliable discrimination between patients with normal ageassociated cognitive decline and patients with pathological cognitive deficits a comprehensive determination and classification of cognitive status in the study sample is essential. Furthermore, it also might be useful to include dementia patients into samples of future studies to provide change norms and RCI values within the monitoring and staging of dementia patients.

RCIs, as suggested by Jacobson and Truax [8], Chelune et al. [9], Hsu [10] and Temkin et al. [28] (Appendix 1) provide estimates of the probability that an individual's change in test scores is not due to chance, measurement error, practice effects or regression to the mean. The studies included computed RCIs for several standardized neuropsychological instruments, e.g. the MMSE [30], which is one of the most widely used screening instruments for cognitive impairment in clinical practice [37]. In general, tests of reviewed studies varied in their coverage from single cognitive dimension tasks to wide ranging neuropsychological batteries. For the detection and assessment of useful quantitative cognitive profiles of patients in psychiatric, neuropsychological or neurological settings it might be necessary to apply instruments with a broader coverage of cognitive key domains. As Sacuiu 
et al. [34] reported, a global low pattern of cognitive performance contributes to the short-term onset prediction of dementia and particularly low memory performance predicted dementia in the long term. Therefore, further standardization and evaluation of RCI scores is needed for more comprehensive neuropsychological instruments, e.g. the CERAD neuropsychological battery [38, 39].

Accurate quantification of cognitive impairment and/ or improvement requires reliable and valid psychometric instruments, which are sensitive to minor changes in cognition. Criticism in the literature regards the ability and sensitivity of assessment tools to differentiate mild cognitive impairment and dementia sufferers from healthy elderly controls [2, 40]. Ceiling and floor effects in high- and low-scoring individuals can minimize clinical utility of instruments [41, 42]. Moreover, the availability and application of parallel/alternate test forms may have a crucial impact on test-retest reliability and practice effects within assessments. To the extent that psychometric test properties may limit reliability and validity of the instrument, the determination of RCI scores may result in impaired significance. Most studies included in this review commented only inadequately on these issues. Regarding the clinical significance of cognitive change in the elderly, the reliability, validity and relevance to appropriate cognitive domains, further evaluation is needed for many psychological instruments.

It is well known that performance in cognitive tests and cognitive change can be influenced by confounders and demographical variables, including age, education and gender. For instance, past research has found that MMSE scores are significantly associated with age and education [43]. Thus, the observation of cognitive functioning should address factors that correlate with cognitive function in old age. In this review 2 studies considered such variables, Bird et al. [16] computed RCI values for 2 age groups and Zec et al. [19] provided age-, education- and gender-specific RCI scores. One can hypothesize that due to small sample sizes and/or statistical disadvantages (e.g. identical means and SD of change for different subgroups based on age, gender and educational level) the evaluation of the influence of age, education and gender in other studies has been neglected. In future investigations, these factors should be considered when evaluating change norms for neuropsychological instruments. Furthermore, the worldwide demographic change in population aging will lead to an increased number of elderly people with the risk to develop dementia exponentially increasing with higher age [1]. Due to these trends, future investigations of change scores and RCI values should include representative population-based samples of older individuals, especially those in higher age ranges.

Limitations of the study refer to the clinical usefulness and validity of change score methods. Although RCI methods were found to detect and classify diagnostic change among persons with improving or declining cognitive abilities [7], the definition of 'normal age-associated cognitive decline' and the diagnostic accuracy of RCI methods should be a matter of concern. Other moderator variables than measurement error, practice effects or regression to the mean could have interfered with test results. Not only cognitively impaired or demented individuals were possibly excluded from the study samples due to low test results, but also individuals with a low premorbid intellectual ability, resulting in lower test performance or a one-time extreme low test score. Concerning the diagnostic accuracy of RCI methods, recent findings suggest that changes in test scores can be significantly associated with future dementia, but do not substantially contribute to the prediction of dementia [44]. Hence, further research evaluating and validating RCI methods is needed.

In conclusion, implementation of change norms is versatile, and further assessment of RCIs has enormous implications for clinical practice, research and health care. RCI values allow the identification of changes in cognitive functioning during the course of dementia and diseases leading to dementia. With the recent development of effective antidementia drugs and pharmacological treatments, it is becoming increasingly useful to apply RCI values within pharmacological trials and therapeutic interventions. The current review enlisted RCI scores for a set of neuropsychological instruments, which can be used for dementia diagnosis in clinical practice and research settings. The standardization of reliable and valid neuropsychological tests in this way could improve early detection, prevention and treatment of dementia and diseases leading to dementia in the elderly.

\section{Acknowledgements}

This publication is part of the German Research Network on Dementia (KND) and the German Research Network on Degenerative Dementia (KNDD) and was funded by the German Federal Ministry of Education and Research (grant KND 01GI0431, grant KNDD 01GI0714). 


\section{Appendix 1}

Jacobson and Truax's Method [8]

To define clinically significant change, the reliable change (RC) index was suggested:

$$
R C=\frac{x_{2}-x_{1}}{S_{\text {diff }}}
$$

- $\mathrm{x}_{1}$ is a subject's pre-test score

- $\mathrm{x}_{2}$ is the post-test score

- $\mathrm{S}_{\text {diff }}$ represents the standard error of difference between the 2 scores and is derived directly from the standard error of measurement $S_{\mathrm{E}}$ according to the formula:

$$
S_{\text {diff }}=\sqrt{2\left(S_{E}\right)^{2}}
$$

and 'describes the spread of the distribution of change scores that would be expected if no actual change had occurred'. RC values exceeding $1.96(\mathrm{p}<0.05)$ would be unlikely to occur without real change in post-test scores. RC values larger than $\pm 1.64(\mathrm{p}<0.10)$ would be expected to occur without real change only $10 \%$ of the time by chance (two-tailed prediction), with $5 \%$ of the cases expected in a positive direction and $5 \%$ in a negative direction (onetailed predictions). Thus, RC values objectively indicate whether change in test scores reflects more than measurement error of the psychometric instrument.

\section{Chelune's Method [9]}

In relation to Jacobson and Truax, they defined a RCI to correct for measurement error and practice effects:

$$
R C I=\frac{\left(\left(X_{2}-X_{1}\right)-\left(M_{2}-M_{1}\right)\right)}{S E D}
$$

- $\mathrm{X}_{1}$ is the observed pre-test score

- $\mathrm{X}_{2}$ is the observed post-test score

- $\mathrm{M}_{1}$ is the group mean pre-test score

- $\mathrm{M}_{2}$ is the group mean post-test score

- SED is taken as the standard deviation of the mean observed difference score.

Hsu's Method [10]

An RCI to correct for regression to the mean was formulated:

$$
R C I=\frac{\left(\left(X_{2}-M_{2}\right)-r_{x x}\left(X_{1}-M_{1}\right)\right)}{S E P}
$$

where $\mathrm{X}_{1}, \mathrm{X}_{2}, \mathrm{M}_{1}, \mathrm{M}_{2}$ are as previously defined and SEP (standard error of prediction) equated SD $\left(1-\mathrm{r}_{\mathrm{xx}}^{2}\right)^{1 / 2}$. SD is the standard deviation of the pre-test score and $r_{x x}$ is the reliability coefficient.

Temkin's Method [28]

Temkin et al. suggested a RCI model to improve upon the RCI defined by Jacobson and Truax [8] by including an adjustment for practice effects:

$$
R C I_{p}=\frac{\left(T_{2}-T_{1}\right)-\bar{D}}{S_{D}}
$$

In this model, the difference between the actual $\left(\mathrm{T}_{2}\right)$ and expected retest score is divided by the standard deviation of the difference scores. The expected retest score is the subject's initial baseline score $\left(T_{1}\right)$ plus the mean practice effect seen in the retested normative sample $(\bar{D})$, and the procedure for defining an

\begin{tabular}{|c|c|c|c|c|}
\hline $\begin{array}{l}\text { Neuropsycho- } \\
\text { logical test } \\
\text { dimension }\end{array}$ & Neuropsychological tests & Cognitive abilities/domains covered & Subject's task/test format & $\begin{array}{l}\text { Dura- } \\
\text { tion } \\
\text { (min) }\end{array}$ \\
\hline \multirow[t]{2}{*}{$\begin{array}{l}\text { Attention } \\
\text { and } \\
\text { perception }\end{array}$} & $\begin{array}{l}\text { Silhouettes Test (subtest of } \\
\text { the visual object and space } \\
\text { perception battery; VOSP) }\end{array}$ & - Visual processing and perception & - Naming of 15 animals and 15 common objects & $5-10$ \\
\hline & $\begin{array}{l}\text { Symbol Digit Test ( similar } \\
\text { to the symbol digit } \\
\text { modalities test; SDMT) }\end{array}$ & $\begin{array}{l}\text { - Speed and divided attention, visual } \\
\text { scanning, tracking and motoric speed }\end{array}$ & $\begin{array}{l}\text { - Filling in the numbers that correspond with symbols } \\
\text { according to the key provided } \\
\text { - Score: correct number of substitutions in each } \\
\text { 90-second interval }\end{array}$ & 5 \\
\hline $\begin{array}{l}\text { Executive } \\
\text { functions }\end{array}$ & $\begin{array}{l}\text { Wisconsin Card Sorting } \\
\text { Test (WCST) }\end{array}$ & $\begin{array}{l}\text { - Ability to learn abstract concepts, and } \\
\text { shift and maintain the set } \\
\text { - Frontal lobe functioning and executive } \\
\text { control }\end{array}$ & $\begin{array}{l}\text { - Matching cards (4 stimulus and } 64 \text { response cards) } \\
\text { that are different in color, quantity, and design } \\
\text { - Learning new card matching rules } \\
\text { - Shifting principles, performance scores }\end{array}$ & $10-15$ \\
\hline
\end{tabular}
unusual deviation from the predicted value is the same as in the basic RCI procedure [9].

\section{Appendix 2}

Classification and clinical aspects of neuropsychological tests used in reviewed studies [adapted from 45] 
Appendix 2 (continued)

\begin{tabular}{|c|c|c|c|c|}
\hline $\begin{array}{l}\text { Neuropsycho- } \\
\text { logical test } \\
\text { dimension }\end{array}$ & Neuropsychological tests & Cognitive abilities/domains covered & Subject's task/test format & $\begin{array}{l}\text { Dura- } \\
\text { tion } \\
(\min )\end{array}$ \\
\hline \multirow[t]{5}{*}{$\begin{array}{l}\text { General cognitive } \\
\text { functioning, } \\
\text { neuropsycho- } \\
\text { logical batteries } \\
\text { and assessment } \\
\text { of intelligence }\end{array}$} & $\begin{array}{l}\text { Dementia Rating Scale } \\
\text { (DRS) }\end{array}$ & $\begin{array}{l}\text { - Provides measurement and tracking of } \\
\text { cognitive status in older adults with } \\
\text { cortical impairment } \\
\text { - Early detection, differential diagnosis, } \\
\text { staging of dementia }\end{array}$ & $\begin{array}{l}\text { - Answering } 36 \text { tasks (including } 32 \text { stimulus cards) } \\
\text { covering } 5 \text { subscales (attention, initiation/persevera- } \\
\text { tion, construction, conceptualization and memory) } \\
\text { - Scoring: } 144 \text { points maximum }\end{array}$ & $15-30$ \\
\hline & $\begin{array}{l}\text { Mayo Cognitive Factor } \\
\text { Scores (MCFS) }\end{array}$ & $\begin{array}{l}5 \text { cognitive domains: verbal knowledge, } \\
\text { nonverbal reasoning, attention and } \\
\text { concentration, new learning and delayed } \\
\text { memory }\end{array}$ & $\begin{array}{l}\text { - Administration of the Wechsler Adult Intelligence } \\
\text { Scale-Revised (WAIS-R), Wechsler Memory } \\
\text { Scale-Revised (WMS-R), and the Auditory Verbal } \\
\text { Learning Test (AVLT); calculation of the MCFS }\end{array}$ & $60-90$ \\
\hline & $\begin{array}{l}\text { MicroCog: assessment of } \\
\text { cognitive functioning }\end{array}$ & $\begin{array}{l}-5 \text { cognitive domains: attention/mental } \\
\text { control, memory, reasoning/calculation, } \\
\text { spatial processing, reaction time }\end{array}$ & $\begin{array}{l}\text { - Answering questions and tasks in the long } \\
\text { (18 subtests) and short (12 subtests) form } \\
\text { (computerized) }\end{array}$ & $30-60$ \\
\hline & MMSE/3MS & $\begin{array}{l}\text { - Central cognitive functions, e.g. } \\
\text { orientation, memory, language, } \\
\text { construction }\end{array}$ & $\begin{array}{l}\text { - Answering 30/100 questions and tasks covering } \\
\text { different cognitive domains including orientation, } \\
\text { memory, language, and praxis } \\
\text { - Scoring: } 30 / 100 \text { points maximum }\end{array}$ & $\begin{array}{c}5-10 / \\
10-15\end{array}$ \\
\hline & SIDAM & $\begin{array}{l}\text { - Orientation, immediate recall, short- } \\
\text { term memory, long-term-memory, } \\
\text { intellectual abilities, judgment, verbal } \\
\text { abilities, calculation, visuospatial function, } \\
\text { aphasia and apraxia }\end{array}$ & $\begin{array}{l}\text { - Answering } 55 \text { questions and tasks including the MMSE } \\
\text { - SISCO Score: } 55 \text { points }\end{array}$ & $10-15$ \\
\hline \multirow[t]{3}{*}{ Language } & $\begin{array}{l}\text { Boston Naming Test } \\
\text { (BNT) }\end{array}$ & $\begin{array}{l}\text { - Confrontation naming ability, } \\
\text { visual perception }\end{array}$ & $\begin{array}{l}\text { - Subjects are asked to name } 60 \text { (long form) or } 15 \\
\text { (short form) presented line-drawn objects in subsets } \\
\text { of words used with different frequency of occurrence } \\
\text { in the English language ( } 3 \text { groups of } 5 \text { items); } \\
\text { scoring: } 15 / 60 \text { points maximum }\end{array}$ & $5-10$ \\
\hline & $\begin{array}{l}\text { Graded Naming Test } \\
(\text { GNT) }\end{array}$ & $\begin{array}{l}\text { - Nominal functions, object naming } \\
\text { ability }\end{array}$ & $\begin{array}{l}\text { - Naming } 30 \text { pictures of objects (line drawings) } \\
\text { - Scoring: } 30 \text { points maximum }\end{array}$ & 10 \\
\hline & Verbal fluency & $\begin{array}{l}\text { - Verbal association fluency, executive } \\
\text { control, controlled oral word association } \\
\text { within a limited amount of time }\end{array}$ & $\begin{array}{l}\text { - Subjects are asked to name as many animals as } \\
\text { possible in } 1 \text { min; scoring: total number of different } \\
\text { animals named } \\
\text { - Phonological (letters) categories also available }\end{array}$ & 3 \\
\hline \multirow[t]{3}{*}{$\begin{array}{l}\text { Learning } \\
\text { and memory }\end{array}$} & $\begin{array}{l}\text { California Verbal } \\
\text { Learning Test (CVLT) }\end{array}$ & $\begin{array}{l}\text { - Episodic verbal learning, organization } \\
\text { and memory }\end{array}$ & $\begin{array}{l}\text { - Subjects are asked to learn and remember verbal } \\
\text { material (word lists A/B, } 16 \text { words per list) in multiple } \\
\text { trials (Standard, Alternate and Short Forms) }\end{array}$ & 50 \\
\hline & $\begin{array}{l}\text { Recognition Memory } \\
\text { Test (RMT) }\end{array}$ & $\begin{array}{l}\text { - Early memory changes associated with } \\
\text { dementia and brain damages }\end{array}$ & $\begin{array}{l}\text { - Two recognition tasks: one for words and one for } \\
\text { unfamiliar faces }\end{array}$ & $<15$ \\
\hline & $\begin{array}{l}\text { Rey Auditory Verbal } \\
\text { Learning test (Rey AVLT) }\end{array}$ & $\begin{array}{l}\text { - Immediate memory span, new learning, } \\
\text { susceptibility to interference, delayed } \\
\text { recall and recognition }\end{array}$ & $\begin{array}{l}\text { - Presentation and recall of a word list (A/B, } 15 \text { words) } \\
\text { - After presentation and recall of a second word list, the } \\
\text { subject is asked to recall the first word list }\end{array}$ & $10-15$ \\
\hline
\end{tabular}

\section{References}

1 Ferri CP, Prince M, Brayne C, Brodaty $\mathrm{H}$, Fratiglioni L, Ganguli M, Hall K, Hasegawa $\mathrm{K}$, Hendrie H, Huang Y, Jorm A, Mathers C, Menezes PR, Rimmer E, Scazufca M: Global prevalence of dementia: a Delphi consensus study. Lancet 2005;366:2112-2117.

2 Petersen RC, Stevens JC, Ganguli M, Tangalos EG, Cummings JL, DeKosky ST: Practice parameter: early detection of dementia: mild cognitive impairment (an evidence-based review). Report of the Quality Standards Subcommittee of the American Academy of Neurology. Neurology 2001;56:1133-1142.

-3 Winblad B, Palmer K, Kivipelto M, Jelic V, Fratiglioni L, Wahlund LO, Nordberg A, Backman L, Albert M, Almkvist O, Arai H,
Basun H, Blennow K, de Leon M, DeCarli C, Erkinjuntti T, Giacobini E, Graff C, Hardy J, Jack C, Jorm A, Ritchie K, van Duijn C, Visser P, Petersen RC: Mild cognitive impairment - beyond controversies, towards a consensus: report of the International Working Group on Mild Cognitive Impairment. J Intern Med 2004;256:240-246. 
4 American Psychiatric Association: Diagnostic and Statistical Manual of Mental Disorders-DSM-IV-TR, ed 4. Washington, American Psychiatric Association, 2000.

5 Hensel A, Riedel-Heller SG: Measuring cognitive change in patients with suspected dementia - change norms are lacking for psychometric instruments (in German). Psychiatr Prax 2008;35:251-254.

-6 Collie A, Maruff P, Makdissi M, McStephen M, Darby DG, McCrory P: Statistical procedures for determining the extent of cognitive change following concussion. Br J Sports Med 2004:38:273-278.

-7 Frerichs RJ, Tuokko HA: A comparison of methods for measuring cognitive change in older adults. Arch Clin Neuropsychol 2005; 20:321-333.

-8 Jacobson NS, Truax P: Clinical significance - a statistical approach to defining meaningful change in psychotherapy research. J Consult Clin Psychol 1991;59:12-19.

-9 Chelune GJ, Naugle RI, Lüders H, Sedlak J, Awad IA: Individual change after epilepsy surgery: practice effects and base-rate information. Neuropsychology 1993;7:41-52.

10 Hsu LM: Caveats concerning comparisons of change rates obtained with five methods of identifying significant client changes: comment on Speer and Greenbaum (1995). J Consult Clin Psychol 1999;67:594-598.

- 11 Licht EA, McMurtray AM, Saul RE, Mendez MF: Cognitive differences between early- and late-onset Alzheimer's disease. Am J Alzheimers Dis Other Demen 2007;22:218-222.

12 Kelley BJ, Boeve BF, Josephs KA: Cognitive and noncognitive neurological features of young-onset dementia. Dement Geriatr Cogn Disord 2009;27:564-571.

-13 Gaugler JE, Yu F, Krichbaum K, Wyman JF: Predictors of nursing home admission for persons with dementia. Med Care 2009;47: 191-198.

14 Mols F, Vingerhoets AJ, Coebergh JW, van de Poll-Franse LV: Quality of life among longterm breast cancer survivors: a systematic review. Eur J Cancer 2005;41:2613-2619.

- 15 Luppa M, Luck T, Weyerer S, Konig HH, Brahler E, Riedel-Heller SG: Prediction of institutionalization in the elderly. A systematic review. Age Ageing 2010;39:31-38.

- 16 Bird CM, Papadopoulou K, Ricciardelli P, Rossor MN, Cipolotti L: Test-retest reliability, practice effects and reliable change indices for the recognition memory test. Br J Clin Psychol 2003;42:407-425.

-17 Bird CM, Papadopoulou K, Ricciardelli P, Rossor MN, Cipolotti L: Monitoring cognitive changes: psychometric properties of six cognitive tests. Br J Clin Psychol 2004;43: 197-210.

18 Raymond PD, Hinton-Bayre AD, Radel M, Ray MJ, Marsh NA: Test-retest norms and reliable change indices for the MicroCog Battery in a healthy community population over 50 years of age. Clin Neuropsychol 2006;20: 261-270.
19 Zec RF, Markwell SJ, Burkett NR, Larsen DL: A longitudinal study of confrontation naming in the 'normal' elderly. J Int Neuropsychol Soc 2005; 11:716-726.

20 Hensel A, Angermeyer MC, Zaudig M, Riedel-Heller SG: Measuring cognitive change in older adults: reliable change indices for the SIDAM. J Neurol 2007;254:91-98.

-21 Hensel A, Angermeyer MC, Riedel-Heller SG: Measuring cognitive change in older adults: reliable change indices for the MiniMental State Examination. J Neurol Neurosurg Psychiatry 2007;78:1298-1303.

22 Pedraza O, Smith GE, Ivnik RJ, Willis FB, Ferman TJ, Petersen RC, Graff-Radford NR, Lucas JA: Reliable change on the Dementia Rating Scale. J Int Neuropsychol Soc 2007; 13:716-720.

23 Tombaugh TN: Test-retest reliable coefficients and 5-year change scores for the MMSE and 3MS. Arch Clin Neuropsychol 2005;20:485-503.

24 Ivnik RJ, Smith GE, Lucas JA, Petersen RC, Boeve BF, Kokmen E, Tangalos EG: Testing normal older people three or four times at 1 to 2-year intervals: defining normal variance. Neuropsychology 1999;13:121-127.

25 Knight RG, McMahon J, Skeaff CM, Green TJ: Reliable Change Index scores for persons over the age of 65 tested on alternate forms of the Rey AVLT. Arch Clin Neuropsychol 2007;22:513-518.

26 Woods SP, Delis DC, Scott JC, Kramer JH, Holdnack JA: The California Verbal Learning Test - second edition: test-retest reliability, practice effects, and reliable change indices for the standard and alternate forms. Arch Clin Neuropsychol 2006;21:413-420.

27 Busse A, Aurich C, Zaudig M, Riedel-Heller $\mathrm{S}$, Matschinger $\mathrm{H}$, Angermeyer MC: Ageand education-specific reference values for the cognitive test of the SIDAM (Structured interview for the diagnosis of dementia of the Alzheimer type, multi-infarct dementia and dementias of other etiology according to ICD-10 and DSM-IV) (in German). Z Gerontol Geriatr 2002;35:565-574.

28 Temkin NR, Heaton RK, Grant I, Dikmen SS: Detecting significant change in neuropsychological test performance: a comparison of four models. J Int Neuropsychol Soc 1999;5:357-369.

29 Maassen GH: Principles of defining reliable change indices. J Clin Exp Neuropsychol 2000;22:622-632.

-30 Folstein MF, Folstein SE, McHugh PR 'Mini-mental state': a practical method for grading cognitive state of patients for clinician. J Psychiatr Res 1975;12:189-198.

- 31 Teng EL, Chui HC: The Modified MiniMental State (3MS) examination. J Clin Psychiatry 1987;48:314-318.

32 Tombaugh TN, McDowell I, Kristjansson B, Hubley AM: Mini-Mental State Examination (MMSE) and the modified MMSE (3MS): a psychometric comparison and normative data. Psychol Assess 1996;8:48-59.
33 Chen P, Ratcliff G, Belle SH, Cauley JA, DeKosky ST, Ganguli M: Patterns of cognitive decline in presymptomatic Alzheimer disease: a prospective community study. Arch Gen Psychiatry 2001;58:853-858.

34 Sacuiu S, Gustafson D, Johansson B, Thorvaldsson V, Berg S, Sjogren M, Guo X, Ostling S, Skoog I: The pattern of cognitive symptoms predicts time to dementia onset. Alzheimers Dement 2009;5:199-206.

- 35 Amieva H, Le Goff M, Millet X, Orgogozo $J M$, Peres K, Barberger-Gateau P, JacqminGadda H, Dartigues JF: Prodromal Alzheimer's disease: successive emergence of the clinical symptoms. Ann Neurol 2008;64: 492-498.

36 Dikmen SS, Heaton RK, Grant I, Temkin NR: Test-retest reliability and practice effects of Expanded Halstead-Reitan neuropsychological test battery. J Int Neuropsychol Soc 1999;5:346-356.

-37 Cullen B, O’Neill B, Evans JJ, Coen RF, Lawlor BA: A review of screening tests for cognitive impairment. J Neurol Neurosurg Psychiatry 2007;78:790-799.

- 38 Morris JC, Mohs RC, Rogers H, Fillenbaum G, Heyman A: Consortium to establish a registry for Alzheimer's disease (CERAD) clinical and neuropsychological assessment of Alzheimer's disease. Psychopharmacol Bull 1988;24:641-652.

-39 Morris JC, Heyman A, Mohs RC, Hughes JP, Vanbelle G, Fillenbaum G, Mellits ED, Clark C: The Consortium to Establish A Registry for Alzheimers Disease (CERAD). 1. Clinical and neuropsychological assessment of Alzheimer's disease. Neurology 1989;39:11591165.

40 Lonie JA, Tierney KM, Ebmeier KP: Screening for mild cognitive impairment: a systematic review. Int J Geriatr Psychiatry 2009;24: 902-915.

41 Busch RM, Chapin JS: Review of normative data for common screening measures used to evaluate cognitive functioning in elderly individuals. Clin Neuropsychol 2008;22:620650

42 Woodford HJ, George J: Cognitive assessment in the elderly: a review of clinical methods. QJM 2007;100:469-484.

43 Harvan JR, Cotter VT: An evaluation of dementia screening in the primary care setting. J Am Acad Nurse Pract 2006;18:351-360.

- 44 Hensel A, Luck T, Luppa M, Glaesmer H, Angermeyer MC, Riedel-Heller SG: Does a reliable decline in Mini Mental State Examination total score predict dementia? Diagnostic accuracy of two reliable change indices. Dement Geriatr Cogn Disord 2009;27:50-58.

45 Strauss E, Sherman EMS, Spreen O: A Compendium of Neuropsycholocical Tests: Administration, Norms, and Commentary, ed 3. New York, Oxford University Press, 2006. 